\title{
Effect of Saline Water on Emergence and Early Seedling Growth of Tomato (Solanum lycopersicum) at Wolaita Sodo University, Southwestern Ethiopia
}

\author{
Tigist yisahak Brihan yemata \\ Department of Horticulture, Wolaita Sodo University, Sodo, Ethiopia \\ P.O.BOX 138, WolaitaSodo,Ethiopia
}

\begin{abstract}
Experiment was carried out in laboratory of wolaita Sodo University College of Agriculture department of Horticulture during 2019 with the objective of to evaluate effect of different level of sodium chloride $(\mathrm{NaCl})$ on emergence and seedling growth of tomato (Solanum lycopersicum.).design used for the experiment was Completely Randomized design (CRD) consisting of five treatments and three replications (Control, $1.2 \mathrm{mg} / \mathrm{ml}$ : $2.5 \mathrm{mg} / \mathrm{ml}$ : $5.8 \mathrm{mg} / \mathrm{ml}$ and $8.8 \mathrm{mg} / \mathrm{ml}$ ) of $\mathrm{NaCl}$. Analysis of variance was tested for all treatments at probability level of $(p \leq 0.05)$ the results reveled, leaf width, leaf length and number of root per seedling showed significant difference among treatments while root length, plant height and leaf number shows no significant, from this finding we conclude that all the growth parameters are affected by high concentration of salinity level that is $8.8 \mathrm{mg} / \mathrm{ml}$ and a better performance was counted from $1.2 \mathrm{mg} / \mathrm{ml}$ of NaCl. But further study is needed on the effect of different level of $\mathrm{NaCl}$ on growth performance and yield of tomato because the percent research was focused only on seedling emergence and early seedling growth.
\end{abstract}

Keywords: Tomato, Solanum lycopersicum L., $\mathrm{NaCl}$, growth, seedling performance

DOI: $10.7176 / \mathrm{JBAH} / 10-6-01$

Publication date:March $31^{\text {st }} 2020$

\section{INTRODUCTION}

Tomato (Solanum lycopersicum) belongs to the Solanaceae family. It is native to South and Central America. Tomato is a popular vegetable crop worldwide and it is grown on more than $5 \times 106$ ha with a production of approximately $161 \times 106$ metric tons. Africa and Asia account for more than $80 \%$ of the global tomato area, with about $70 \%$ of world output $(\mathrm{FAO}, 2012)$. Tomato is one of the most popular and widely distributed annual vegetable crops which is cultivated and consumed in most parts of the world, from home gardens and greenhouses to large commercial farms due to its wider adaptability to various agro-climatic conditions (Agyeman et al., 2014).

Currently, tomato is one of the regional export crops of the country being cultivated under both irrigated as well as rain fed conditions (Joosten, 2007). Ambecha et al. (2012) reported that about 32-40\% of smallholders use irrigation (entirely furrow). However, based on the Ministry of Agriculture and Rural Development report in Crop Variety Register (2009) the total area coverage of tomato and its production in Ethiopia are 5,342 ha and 418, $150 \mathrm{q}$ respectively. Then, the total tomato production increased to $556,350 \mathrm{q}$ in 2010 crop year (CSA, 2016). Yet, average yield or productivity of tomato in Ethiopia is low, ranging from 65-240 q ha-1under farmers' conditions, which is very low compared to $250 \mathrm{q} / \mathrm{ha}$ and $400 \mathrm{q} / \mathrm{ha}$ on the demonstration and research plots, respectively as well as compared with average yields of 510, 410, 360 and 340 q ha-1 in America, Europe, Asia and the entire world, respectively (FAOSTAT, 2010). Moreover, growers have been challenged by inconsistent production and low yields. The major problems of the productions of tomato crops are diseases, insect pests, quality, yield, salinity, drought and other (Jaliya, et al., 2007).

It is well documented that in many of the arid and semiarid regions of the Ethiopia and the world, the amount and quality of irrigation water available as well as limited water and hot dry climates frequently cause salinity problem that limit or prevent crop production (Nazarbeygi etal.,2011). It has also been reported that under saline conditions, germination ability of seeds differ from one crop to another and even a significant variation is observed amongst the different varieties of the same crop (Jamil etal., 2005). Plant species vary in how well they tolerate salt-affected soils. Some plants will tolerate high levels of salinity while others can tolerate little or no salinity. The relative growth of plants in the presence of salinity is termed their salt tolerance (Munns, 2002; Neto etal., 2004).Salinity induces specific changes on cell, tissue and organ levels. These changes are physiological, hormonal balance, morphological and anatomical (Ayaz et al., 2000). Salt stress affects many physiological aspects of plant growth. Shoot growth was reduced by salinity due to inhibitory effect of salt on cell division and enlargement in growing point. Early flowering reduced dry matter, increased root: shoot ratio and leaf size caused by salinity may be considered as possible ways of decreasing yield in plant under salt stress condition (Maghsoudi, 2008). The establishment stage of the crop consists of three parts: germination, emergence and early seedling growth; that are particularly sensitive to substrate salinity (Bhattacharjee, 2008). 
This has prompted researchers to study the impact of salinity on plant crops. A number of investigators (Parida and Das, 2005; Hajer et al., 2006) reported that in many crop species seed germination and early seedling growth are the most sensitive developmental stages to salinity stress. Similarly, Parida and Das (2005) confirmed that salt stress affects some major processes such as germination, and speed of germination.

Crop establishment depend on an interaction between seedbed environment and variety at early seedling stages for successful crop production in a saline environment (Hakim et al., 2010). Seed germination is usually the most critical stage in seedling establishment, determining successful crop and seed quality (Hu and Jones, 2004,Bhattacharjee, 2008). Rapid, uniform and complete germination is a prerequisite for successful transplant production and stand establishment in vegetable crops (Demir and Ermis, 2003, Mostafavi et al., 2011). There was limited researches conducted in Wolaita Sodo University on saline effect on tomato and furthermore, it is known that the seed of tomato germination the presence of certain concentrations of $\mathrm{NaCl}$ in the soil, research is necessary to determine which concentrations of salt would not interfere with process of germination and early seedling growth in test crop tomato. Depending on this problem the present research was conducted on the following objectives.

To evaluate the effect of different level of saline $(\mathrm{NaCl})$ water on emergence and subsequent seedling growth of crop tomato.

To identify saline sensitivity and the level of tolerance to saline conditions in emergence and early seedling growth of tomato

\section{MATERIALS AND METHODS}

\subsection{Description of the study area}

wolaita Sodo is situated at $330 \mathrm{~km}$ far from the capital city Addis Ababa in the southwestern part of Ethiopia SNNPRs, The area is geographically located at Latitude $6^{\circ} 59^{\prime} \mathrm{N}$ and Longitude $35^{\circ} 35^{\prime} \mathrm{E}$ with an altitude of 1750 $\mathrm{m}$ above sea level. It has the respective annual mean minimum and maximum rainfall of $1200 \mathrm{~mm}$ and $2000 \mathrm{~mm}$ and an annual average minimum and maximum air temperatures are $22{ }^{\circ} \mathrm{C}$ and $29{ }^{\circ} \mathrm{C}$, respectively (BOALAF, 2009).

\subsection{Experimental materials and procedures}

A high quality clean-healthy tomato (Lycopersim esculentum, Mill. var. Tomato Roma) seeds was used for the study. Medium used for this experiment was prepared with sterilized mixtures of top soil, compost and sand in $2: 1: 1$ ratio respectively. The media mixtures was sterilized using high temperatures (heat) through "solarisation" (The media mixtures were exposed to high temperatures (heat) place $20 \mathrm{~cm}$ layer of mixtures under a plastic thin foil and under the sun) for a week before pot filling as per the recommendation given to guarantee a media free from nematode, insects and pathogens. Soil (The media mixtures) analysis for specific parameters (analyzed for $\mathrm{pH}, \mathrm{EC}$, organic matter, and CEC of the experimental plot before planting) was carried out at soil laboratory of the university.EC ( $\mathrm{mm}$ hos $\left.\mathrm{cm}^{-1}\right)$ :

The soil was analyzed for Electrical Conductivity by using EC meter before planting the seeds and treatment application. Soil $\mathrm{pH}$ : was determined in 1:2.5 soils to water ratio using a glass electrode attached to a digital $\mathrm{pH}$ meter. It was potentiometrically measured in the supernatant suspension of a 1:2.5 soil: liquid mixture. The mixed media was uniformly filled in plastic pots step by step and press down the mixture to avoid larger air space and thereafter randomly assigned on the nursery beds prepared. Before beginning the experiment, solutions was made by dissolving sodium chloride $(\mathrm{NaCl})$ in distilled water at five different concentrations (distilled water as control, $1.2 \mathrm{mg} / \mathrm{ml}, 2.9 \mathrm{mg} / \mathrm{ml}, 5.8 \mathrm{mg} / \mathrm{ml}$ and $8.8 \mathrm{mg} / \mathrm{ml}$ ) and labeled concentrations of salt solutions and then left for $24 \mathrm{~h}$ in order to dissolve; and made ready for use. The salt solution was prepared every three days so that it is relatively fresh for watering the germinating seeds.

\subsection{Experimental design and treatments}

The experiment was arranged as a single factor in a Completely Randomized Design (CRD) with three replications as described by Montgomery (2013). The factor had 5 levels solutions made by dissolving sodium chloride $(\mathrm{NaCl})$ in distilled water (electrical conductivity $(\mathrm{Ec})$ of 0 (distilled water $=$ as control), 1.2, 2.9, 5.8 and $8.8 \mathrm{mg} / \mathrm{ml} \mathrm{NaCl}$ concentrations dissolving in distilled water). In this experiment, the test crop tomato seeds was evaluated in five levels of saline water treatment by using different $\mathrm{NaCl}$ concentrations (Table 1).

The Linear Additive Model (L.A.M.) Procedures of Statistical Analysis System (SAS) computer software (9.2 versions) (SAS Institute, Inc., 2008) was used. 
Table 1: Description of the treatments saline water due to different salt $(\mathrm{NaCl})$ concentrations

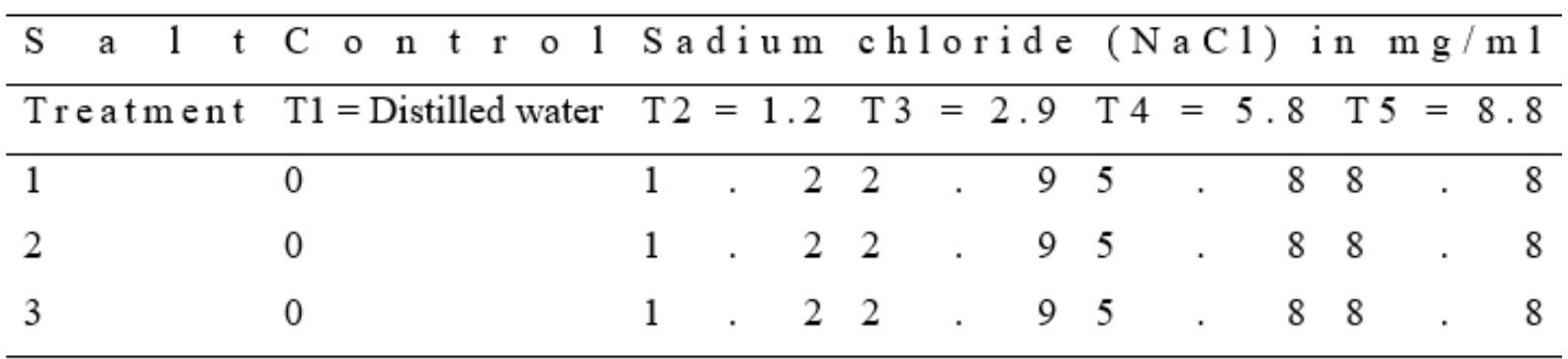

\subsection{Data collection}

During data collection, seedling emergence and growth parameters for each treatment were recorded in the study. Daily observations were made to register the total number of seeds that emerged within each replication up to 14 days after sowing (number of day after which no new emergence was obtained). The number of days from sowing to commencement of emergence was recorded for all studied treatments. The emergence of the seedling was considered to the complete emergence of the seedling from pots potted with uniformly mixed growing media, since this is an indicator of successful field establishment. Accordingly, data on the following parameters where calculated for each study treatment:

Number of leaves per seedling: The average number of leaves per seedling was counted at the end when the true leaves have emerged. The mean number of leaves counted divided by the number of seedlings taken.

Leaf length (cm): The average length of the longest leaf was measured by a ruler at the end of the experiment.

Leaf width $(\mathrm{cm})$ : The average width of leaves at the widest part was measured by a ruler at the end of the experiment.

Plant height $(\mathrm{cm})$ : The height of the plant was measured from randomly taken five seedlings from each replicate within each treatment. The measurement was done using a tape meter (a ruler) from the base of the stem to shoot apex (at a point of the soil level up to the terminal bud) in centimeters at the end of the experiment. The mean height of sampled seedlings was measured divided by number of seedlings taken.

Number of roots per seedling: This parameter was calculated all the profile roots at the end of the experiment.

Root length (cm): Root length of uprooted seedling was measured at a point below the soil level by tape meter/a ruler at the end of the experiment.

\subsection{Data analysis}

Analysis of variance (ANOVA) was computed using SAS 9.4 ver.software for each study character in order to identify the variability among the levels of saline water (solutions made by dissolving sodium chloride $(\mathrm{NaCl})$ in distilled water at five different concentrations) on emergence and subsequent seedling growth in the study test crop tomato (the studied test crop). The least significant Differences (LSD) test at $5 \%$ ( $\mathrm{P} \leq 0.05$ ) probability levels of significance was used for the treatment mean separations whenever significant differences were detected between treatments.

\section{RESULTS AND DISCUSSIN}

The Emerges and early seedling growth of tomato was influenced by different saline water the data analysis investigated that saline has significant effect of seedling growth of tomato, the result is showed in table (table 2 and table 3)

Table 2: effect of saline water on plant height, leaf number and leaf length,

\begin{tabular}{llll}
\hline Treatment & plant height & Leaf number & leaf length \\
\hline control & 21.16 & 3.866 & $3.66 \mathrm{a}$ \\
$\mathbf{1 . 2} \mathbf{~} \mathbf{~ g / m l}$ & 21.06 & 4.06 & $4.133 \mathrm{a}$ \\
$\mathbf{2 . 5} \mathbf{~} \mathbf{m} / \mathbf{m l}$ & 23.53 & 3.93 & $3.67 \mathrm{a}$ \\
$\mathbf{5 . 8} \mathbf{~} \mathbf{~ g} / \mathbf{m l}$ & 25.2 & 3.53 & $3.9 \mathrm{a}$ \\
$\mathbf{8 . 8} \mathbf{~} \mathbf{g} / \mathbf{m l}$ & 23.66 & 3.2 & $3 \mathrm{~b}$ \\
$\mathbf{l s d} \mathbf{5 \%}$ & 4.97 & 2.21 & 0.824 \\
cv & 2.549 & 3.85 & 1.70 \\
\hline
\end{tabular}

$\mathrm{CV}=$ cofficient of variation $\mathrm{LSD}=$ Least significant different

\subsection{Effect of saline water on plant height}

The result in (table 2) shows that different seedling growth is inhibited by salinity stress and there was no significant difference for all treatments that is for controlled and all amounts of $\mathrm{NaCl}$ for plant height at $\mathrm{p} \leq$ 
0.05). This result is in agreement with Brihanu and Brihane(2014) who reported that when salinity stress was increased from 0 to $9 \mathrm{dSm}$ while there was no significant difference in shoot fresh weight, shoot dry weight and leaf number. Also this finding is in agreement with Ali and Gholam (2014) who reported that Effect of salinity level up to $25 \mathrm{mM}$ was negligible and there was no difference between treated and control groups on growth indices.

\subsection{Effect of saline water on number leaf}

As shown in (table 2) the result obtained for number of leaves showed that different seedling growth has different number of leaves as the salinity level increases the number of leaves decrease even if there was statically no significant difference obtained for all treatments on leaf number at $(p \leq 0.05)$ these results were supported by the findings of Brihanu and Brihane (2014) who mentioned that asignificant reduction of leaf number was observed between seed tyeps when salinity stress increases from 0 to 9 dsm while there was no significant difference between salinity level of 0,5 and $7 \mathrm{dsm}$ on leaf number. This finding is also in agreement with the finding of Rahaman etal,.(2008) who reported that reduction of leaf number were believed to be due to slow or less mobilization of reserved foods. The present finding is in agreement with the finding of other (Kaya etal,. 2005,pessarakli and kopec,2009).

\subsection{Effect of saline water on leaf length}

The analysis of variance showed that there is a significant diference on leaf length as the salinity level increses the length of leaves were affected by the stress (table 2). there were no seginicat difference obtained for salinity level of $1.2,2.5$ and $5.8 \mathrm{mg} / \mathrm{ml}$ of $\mathrm{NaCl}$ but as the level of $\mathrm{NaCl}$ increased to $8.8 \mathrm{mg} / \mathrm{ml}$ leaf lengeth were affected significantly.this finding is in agreement with the finding of Mohammad (2011) and Ali and Gholam (2014) whoreported taht when salinity level increase, seedlings radicle and plumulelength decrease. Salinity environment have shorter plumule and $\mathrm{NaCl}$ more than other salinity factors gas deterrent impact on embryo tissues appearance (Khan and Ungar, 1997) additionally in agremment with (Katergi et al., 1994; Khan and Ungar, 1985) studies on germinated seeds in salinity environments have short root and shoot and $\mathrm{NaCl}, \mathrm{has}$ on extreme deterrence effect on embryo tissues' development rather than other salinity materials

Table 3: effect of saline water on leaf width, root number and root length

\begin{tabular}{|c|c|c|c|}
\hline Treatment & leaf width & Root number & Root length \\
\hline control & $1.16 \mathrm{a}$ & $5.7 \mathrm{a}$ & 3 \\
\hline $1.2 \mathrm{mg} / \mathrm{ml}$ & $1.126 \mathrm{a}$ & $7.2 \mathrm{a}$ & 3.26 \\
\hline $2.5 \mathrm{mg} / \mathrm{ml}$ & $0.99 b$ & $3.7 \mathrm{~b}$ & 3.6 \\
\hline $5.8 \mathrm{mg} / \mathrm{ml}$ & $0.78 \mathrm{~b}$ & $3.8 \mathrm{~b}$ & 2.83 \\
\hline $8.8 \mathrm{mg} / \mathrm{ml}$ & $0.57 \mathrm{c}$ & $2.6 \mathrm{~b}$ & 2.86 \\
\hline Isd $5 \%$ & 0.138 & 2.929 & 1.39 \\
\hline cv & 2.87 & 3.44 & 3.44 \\
\hline
\end{tabular}

$\mathrm{CV}=$ cofficient of variation $\mathrm{LSD}=$ Least significant different

\subsection{Effect of saline water on leaf width}

The result from analysis of variance showed that ther were highly significant difference between controlled and $8.8 \mathrm{mg} / \mathrm{ml}$ of $\mathrm{NaCl}$ level, and ther is significant difference between the controlled 2.5 and $8.8 \mathrm{mg} / \mathrm{ml} \mathrm{of} \mathrm{Na} \mathrm{Cl}$ (table 3 ) this indicates that when the level of salt concentration increses the size of leaves become shriveled and have small size this might be because of nutrient movement and stored food shortage. The present result agrees with Rahman et al,.(2008) reported a reduction were beleved to be due to slow or less mobilization of reserved foods, suspending the cell division, enlarging and injuring hypocotyls with increase in salt concentration.

\subsection{Effect of saline water on root number and root length}

The present result showed that a salt concentration level $1.2 \mathrm{mg} / \mathrm{ml}$ have the higher root number followed by the controlled and the lowest root number was recorded from $8.8 \mathrm{mg} / \mathrm{ml}$ salt concentration. The result shows that there is a significant difference between the controlled and different salt concentration levels except for 1.2 $\mathrm{mg} / \mathrm{ml}$ (table 3 ), this might be due to the salt accumulation around the root zone affectes the number of roots. This finding is in agreement with the finding of Brihanu and Brihane (2014) and Ali and Gohlam (2014) who mentioned indices of root and shoot growth are those plant growth indices quickly affected by salt stress. The result for root length shows that as the salt concentration increases root length decrees this is due to high concentration affects the root and nutrient absorption. The present result is in agreement with the finding of (Ali and gholam,2014) who reported that fresh weight of plumule was not significantly different between cal ji and flat ch irani and Reduced fresh weight of root and stem was as a result of salt stress was reported by (Mortezai nejad and Rezai, 2009). 


\section{CONCLUSION}

Tomato is one of the most extended and well-known fruit vegetables cultivated in Ethiopia. It is widely accepted and community used in variety of dishes as raw, cooked or processed products more than any other vegetables. The seedling growth of tomato plant was significantly affected by different saline soil.

The experiments were laid out in Completely Randomized design (CRD) consisting of five treatments and three replications to evaluate different saline consentration level on tomato seedling emergence and growth. The saline water treatments were used either alone or in combination Top soil Sand, and compost (Control 1.2g: 2.5g: $5.8 \mathrm{~g}$ :and $8.8 \mathrm{~g}$ ) of $\mathrm{NaCl}$. Analysis of variance was tested for all treatments at probability level of $(\mathrm{p} \leq 0.05)$ According to Analysis of variances results among the parameters leaf width, leaf length and number of root per seedling showed significantly influenced by deferent level of $\mathrm{NaCl}$ salinity while root length, plant height and leaf number shows no significant to the response of different level of $\mathrm{NaCl}$. The maximum leaf length was recorded from $1.2 \mathrm{~g}$ of $\mathrm{Nacl}$ and the minimum leaf length was from $8 \mathrm{~g}$ of $\mathrm{NaCl}$ which is $4.13 \mathrm{~cm}$ and $3 \mathrm{~cm}$ respectively, result for leaf width shows that the larger leaf which was recorded from the controlled while the narrower from $8.8 \mathrm{~g}$ of $\mathrm{NaCL}$ which is $1.6 \mathrm{~cm}$ and $0.57 \mathrm{~cm}$ respectively, also the minimum root number was recorded from $8.8 \mathrm{~g}$ of $\mathrm{NaCl}$ and the maximum from $1.2 \mathrm{~g}$ which is 2.6 and 7.2 respectively from this finding we conclude that all the growth parameters are affected by high concentration of salinity level that is $8.8 \mathrm{~g}$ and a better performance was counted from $1.2 \mathrm{~g}$ of $\mathrm{NaCl}$,so it is better to use a soil which have small concentration of $\mathrm{NaCl}$ for seedling germination and seedling growth of tomato. But further study is needed on the effect of different level of saline concentration on growth performance and yield of tomato because theperecent research was focused only on seedling emergence and early seedling growth of tomato

\section{REFE RENCES}

Agyeman K, Osei-Bonsu I, Berchie JN, Osei MK, Mochiah MB, Lamptey JN, Kingsley O,Bolfrey-Arku G.(2014). Effect of poultry manure and different combinations of inorganic fertilizers on growth and yield of four tomato varieties in Ghana. Agricultural Science;2(4):27

Ali Salehi Sardoei1*and Gholam Abbas Mohammadi. (2014).Study of salinity effect on germination of tomato. European Journal of Experimental Biology, 4(1): 283-287

Ambecha O. Gemechis, Paul C. Struik and BezabihEmana. (2012). Tomato production in Ethiopia: constraints and opportunities. Wageningen University and Research Centre, Centre for Crop Systems Analysis (CSA), Wageningen, The Netherlands.

Bagal SD, Sheikh GA, Adsule RN.(2008). Influence of different levels of N, P and K fertilizers on the yield and quality of tomato. J. Maharashtra Agric. Univ. ;14(2):158-160.

Berhanu Abraha Tsegay and Berhane Gebreslassie,(2014).The effect of salinity $(\mathrm{NaCl})$ on germination and early seedling groeth of Lathyrus sativus and Pisum sativum var.abyssinicum.

Bhattacharjee S, (2008). "Triadimefon pretreatment protects newly assembled membrane system and causes upregulation of stress proteins in salinity stressed Amaranthuslividus L. during early germination". J. Environ. Biol, 29, , pp. 805-810.

Food and Agriculture Organization (FAO) (2012). Food and Agricultural Organization statistics book on national crop production. Rome, Italy, Food and Agriculture Organization of the United Nations.

Jaliya, M.M, Sani B.M., Lawal A.O, Murtala, G.B. (2007). Effect of irrigation frequency on productivity of heat tolerant tomato varieties at Samaru-Zaria.13th National irrigation and drainage seminar. Minna 105-108pp

Joostan (2007).Development Strategy for the Export- Oriented Horticulture in Ethiopia

Katergi, N., J.W. Van Hoorn, A. Hamdy, F. Karam and M. Mastrortilli,( 1994). Effect of salinity on emergence and on water stress early seedling growth of sunflower and maize. Agricultural Water Management, 26: 8191.

Kaya MD,Kaya G,Kolsarici O (2005). Effects of $\mathrm{NaCl}$ concentration on germination and emergence of some Brasica species. J. Agric.Sci. 11:448-452.

Khan, M.A. and I.A. Ungar, (1985). The role of hormones in regulators the germination of polymorphic seeds and early seedling growth of Atriplex triangularis under saline condition. Physiology Plantarum, 63: 109113.

Khan, M.A. and I.A. Ungar, (1997). Germination responses of subtropical annual halophyte zygophyllum simplex. Seed Science and Technology, 25: 83-91.

Ministry of Agriculture and Rural Development report in Crop Variety Register (2009)

MOFA, Agriculture in Ghana: Facts and Figures (2010). Statistics, Research and Information

Mohammad Hosein Bijeh Keshavarzi ,(2011). Effect of Salt Stress on Germination and Early Seedling Growth of Savory (Satureja hortensis) Australian Journal of Basic and Applied Sciences, 5(12): 3274-3279, 2011 ISSN 1991-8178

Mortezai nejad F and P Rezai. Agricultural Research Letters, (2009). 1(2): 34-45.

Munns R (2002). Comparative physiology of salt and water stress. Plant Cell and Environ. 25: 239-250. 
Parida AK, Das AB.(2005). Salt tolerance and salinity effects on plant: a review. Ecotoxical Environ Safety. ;60:324-349. doi: 10.1016/j.ecoenv.2004.06.010. [PubMed] [Cross Ref]

Pessaraki M. Kopec DM (2009). Screening various Ryegrass cultivars for salt tolerance J.Food Agric. Environ 7:739-743.

Rahman m, Soomro U.Zahoor-ul-Hag M, Gul SH (2008). Effect of NaCl Salinity on Wheat(Triticum aestivumL.) cultivars. World J.Agriculture Sci 4:398-403

The federal democratic republic of ethiopia central statistical agency agricultural sample survey 2015/2016 (2008 E.C.) 